\title{
Blackfriars
}

say, "Jesus was not certain of His Divinity," provided that we understood (though we did not express) the conditions ; even as it is lawful for us to say the greater things, "God had a mother. God died," although we do not express but merely understand the conditions.

Vincent McNabB, O.P.

\section{THE WEB}

T WONDER, dearest, what you do,

1 The while I sit and weave for you

A silver-shining web of prayer,

To hold you in its silken lair.

By night and day I weave it round,

Till you are fettered fast, and bound.

Your body sweet I snare from harm, In the close magic of its charm.

Your golden head I wind about,

To keep all thoughts of sadness out.

Your darling hands, your darling feet, Are safe within its meshes sweet.

For Heaven is ev'ry angel's home,

So lest some fellow-sprite say, "Come,"

And you should strive to spread your wings,

For the glad sound of what he sings,

So fast my web shall wrap you round,

You shall not have this earthly ground.

For I have wrought it strong and well,

And only GoD can break the spell ;

Yea, round His Hands I weave my net

That so He may not break it yet.

Sister Mary Benvenuta, O.P. 